\title{
Desain Kapal Amfibi Water School Bus sebagai Sarana Transportasi Pelajar untuk Rute Pelayaran Kepulauan Seribu - Jakarta Utara
}

\author{
Rainy Renata Renald Rinaldi dan Hesty Anita Kurniawati \\ Departemen Teknik Perkapalan, Fakultas Teknologi Kelautan, Institut Teknologi Sepuluh Nopember \\ (ITS) \\ e-mail: tita@na.its.ac.id
}

\begin{abstract}
Abstrak-Pulau Untung Jawa merupakan salah satu wilayah di Kepulauan Seribu yang tidak memiliki SMA sehingga mengharuskan penduduk yang ingin melanjutkan pendidikan ke tingkat SMA untuk menyeberang ke Jakarta Utara. Para pelajar dari pulau tersebut menyeberang ke sekolah mereka dengan kapal ojek tradisional yang tidak terjamin keselamatannya atau menginap di wilayah mereka bersekolah. Dengan kapal Amfibi Water School Bus, pelajar dapat diantar menyeberangi laut dan berjalan di darat hingga sampai di depan sekolah dengan selamat. Payload dari Water School Bus ini adalah jumlah pelajar SMA di Pulau Untung Jawa. Setelah didapatkan jumlah payload, kemudian dicari nilai deadweight dan penentuan ukuran utama untuk dilakukan perhitungan teknis yang meliputi perhitungan stabilitas, perhitungan trim, dan perhitungan freeboard dan dilanjutkan dengan mendesain Rencana Garis, Rencana Umum, dan menghitung biaya pembangunannya. Dari desain kapal amfibi Water School Bus dengan payload 59 pelajar SMA beserta 1 orang sopir, didapatkan ukuran utama kapal Lpp: 14.27 m; B: $2.5 \mathrm{~m}$; H: $4 \mathrm{~m}$; T: $1.6 \mathrm{~m}$ dengan biaya pembangunan sebesar $\mathrm{Rp}$ $2,393,414,848.59$.
\end{abstract}

Kata Kunci-Desain Kapal, Kapal Amfibi, Water School Bus, Pulau Untung Jawa, Kepulauan Seribu.

\section{PENDAHULUAN}

$\mathrm{K}$ EPULAUAN Seribu adalah sebuah kabupaten administrasi di Daerah Khusus Ibukota Jakarta, Indonesia yang wilayahnya meliputi gugusan kepulauan di Teluk Jakarta. Terdiri dari pulau-pulau karang sebanyak 105 buah dengan total luas wilayah daratan sebesar $8,7 \mathrm{~km}^{2}$, jumlah penduduk di kepuauan seribu sebanyak lebih kurang 20.000 jiwa yang tersebar di sebelas pulau-pulau kecil berpenghuni. Pada kepulauan ini terdapat sejumlah 17 sekolah yang tersebar di Pulau Harapan, Pulau Kelapa, dan Pulau Panggang dan terdapat 3 sekolah jenjang menengah atas yaitu SMA Negeri di Pulau Pramuka, SMKN 61 dan 1 MA PKU di Pulau Tidung. Penyebaran sekolah ini sangat tidak merata dan jumlah SMA terlalu sedikit karena siswa di Kepulauan Seribu sendiri mencapai 500 jiwa. Pulau-pulau yang tidak memiliki SMA antara lain adalah Pulau Untung Jawa, Pulau Lancang, Pulau Pari, Pulau Panggang, Pulau Kelapa dan Pulau Harapan. Hal tersebut mengharuskan para penduduk yang ingin melanjutkan pendidikan ke tingkat SMA untuk bersekolah di pulau lain atau di Jakarta [1].

Saat ini, sarana transportasi antar pulau yang disediakan oleh Dinas Transportasi dan Perhubungan juga Dinas
Pendidikan Kabupaten Kepulauan Seribu untuk pelajar adalah fasilitas kapal penyeberangan yang disebut Kapal Sekolah [2]. Telah tersedia tiga fleet Kapal Sekolah berkapasitas 60-70 orang per kapal untuk memfasilitasi penyeberangan pelajar antar pulau di dalam area Kepulauan Seribu. Kondisi rute pelayaran yang terbatas hanya di beberapa pulau dan di dalam Kepulauan Seribu menimbulkan masalah karena hal tersebut memperkecil kesempatan pelajar yang harus menyeberang ke kawasan Jakarta, khususnya Jakarta Utara untuk bersekolah.

Untuk mengatasi masalah tersebut, dibutuhkan desain kapal amfibi Water School Bus yang dapat mengangkut pelajar untuk menyeberangi pulau dan mengantar mereka ke sekolahnya masing-masing di Jakarta Utara dengan selamat. Kendaraan amfibi merupakan kendaraan yang dapat beroperasi di perairan dan darat, sehingga pelajar dapat menyeberangi pulau melalui laut dan langsung diantar ke sekolah tanpa perlu berganti kendaraan di darat. Lokasi Jakarta dan Kepulauan Seribu terhadap Pulau Jawa dapat dilihat pada Gambar 1.

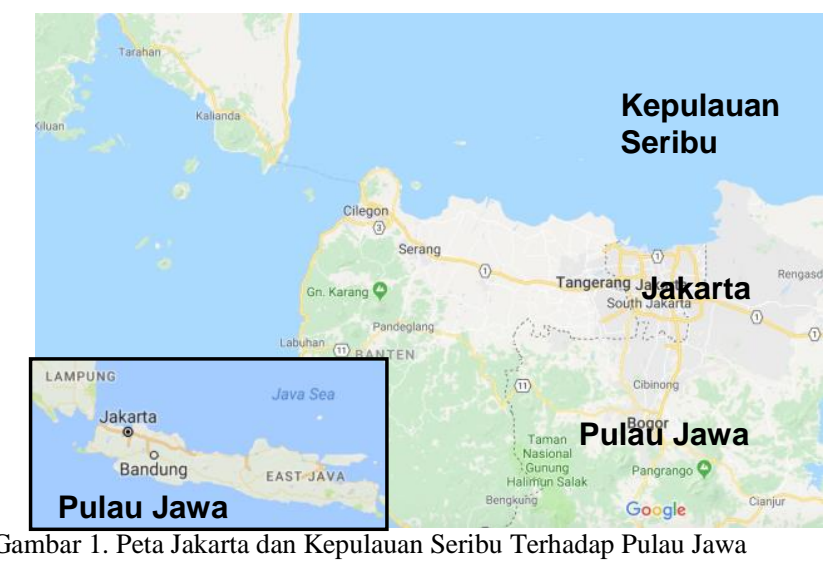

\section{STUDI LITERATUR}

\section{A. Proses Desain}

Dalam proses mendesain kapal, terdapat sebuah teknik berulang dimana prosesnya terangkum dalam sebuah alur melingkar yang disebut Spiral Design yang bertujuan menghasilkan output desain yang maksimal dan sesuai keinginan. Tedapar 4 (empat) tahapan proses desain, yaitu [3]:

1) Concept Design

2) Preliminary Design 


\section{3) Contract Design \\ 4) Detail Design}

\section{B. Metode Forecasting}

Metode Forecasting atau biasa disebut dengan metode peramalan merupakan kegiatan menganalisis kondisi berdasarkan suatu data yang dapat bersifat kuantitatif atau kualitatif pada masa lalu. Peramalan secara kuantitatif menggunakan model matematis yang beragam. Semakin sedikit selisih penyimpangan yang terjadi, semakin baik metode yang diterapkan [4]. Metode kuantitatif dapat diterapkan dengan syarat:

1) Tersedia data dan informasi masa lalu

2) Data dan informasi tersebut dapat dikunatitatifkan secara numerik

3) Diasumsikan beberapa aspek masa lalu akan terus berlanjut di masa datang

\section{Faktor Teknis Desain Kapal}

Dalam mendesain kapal, terdapat faktor-faktor teknis yang harus diperhitungkan sehingga dapat diperoleh karakteristik desain kapal yang sesuai dengan owner requirement. Faktorfaktor tersebut antara lain adalah penentuan ukuran utama, perhitungan berat kapal, perhitungan koefisien bentuk badan kapal, perhitungan hambatan, pemeriksaan stabilitas kapal, perhitungan freeboard, perhitungan trim, desain Rencana Garis dan Rencana Umum.

\section{Karakteristik Sistem Propulsi Waterjet}

Sistem water jet umumnya terdiri dari sistem pompa (pump system) dan sistem saluran (ducting system). Tenaga mekanik dikonversikan dengan pompa menjadi tenaga hidrolis. Sedangkan sistem saluran berfungsi untuk mengarahkan laju aliran dari lingkungan ke pompa dan dari pompa untuk kembali ke lingkungan. Keberadaan sistem pompa pada sistem propulsi water jet sama halnya dengan keberadaan motor pendorong pokok pada kapal-kapal lainnya. Akan tetapi pada sistem ini masih harus ada penggerak utama yang digunakan untuk menggerakkan pompa water jet, dapat berupa mesin diesel, turbin gas, motor listrik dan yang lainnya sejauh masih memungkinkan untuk digunakan. [5]

\section{E. Tinjauan Rute Pelayaran}

Pulau Untung Jawa merupakan pulau berpenghuni yang berlokasi di kelurahan Untung Jawa, kecamatan Kepulauan Seribu Selatan. Pulau ini merupakan pusat pemerintahan kelurahan Pulau Untung Jawa. Dengan luas 40 ha, jumlah penduduk yang bertempat tinggal di Pulau Untung Jawa adalah 2184 jiwa [6].

Pulau Untung Jawa merupakan salah satu pulau di Kepulauan Seribu yang tidak memiliki SMA. Dikarenakan lokasinya yang dekat dengan Jakarta Utara, banyak penduduk yang mencari tempat tinggal sementara di kawasan Jakarta Utara untuk bersekolah. Hal tersebut juga mengakibatkan banyaknya penduduk yang tidak melanjutkan pendidikan ke tingkat SMA. Peta Rute Pelayaran dari Jakarta Utara ke Pulau Untung Jawa dan sebaliknya dapat dilihat pada Gambar 2 dan lokasi Muara Angke dan SMA disekitarnya dapat dilihat pada Gambar 3.
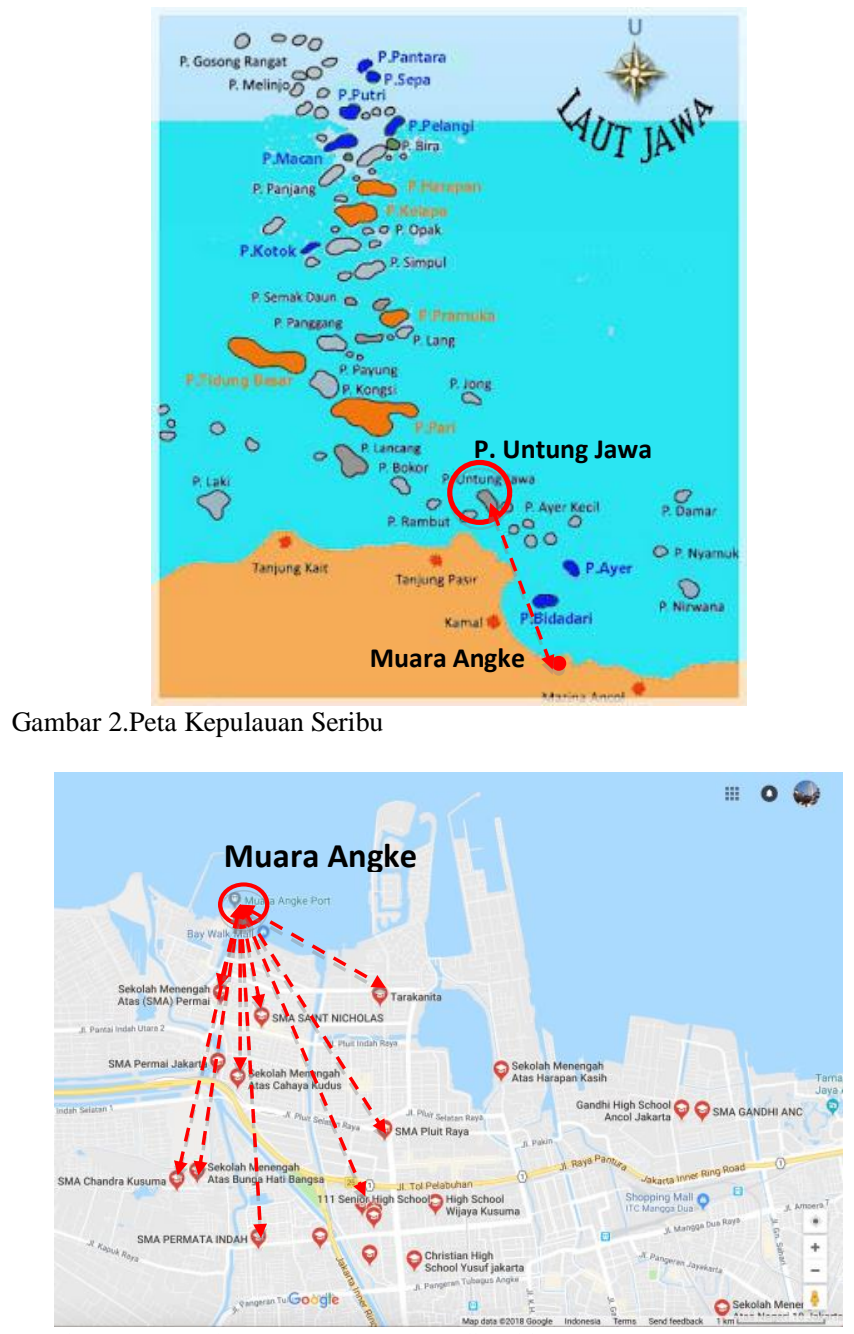

Gambar 3. Peta Jakarta Utara dan SMA di Sekitarnya

\section{F. Kendaraan Amfibi}

Kendaraan amfibi merupakan kendaraan yang dapat beroperasi di dua alam, yaitu di darat dan di perairan. Perkembangan teknologi yang semakin pesat menunjang peneliti untuk berinovasi sehingga jenis kendaraan amfibi menjadi cukup umum digunakan untuk keseharian [7].

Kendaraan Water Bus merupakan hasil dari perkembangan teknologi yang pesat dan inovatif. Jenis transportasi amfibi ini berbentuk bus dan dapat mengangkut hingga 60 orang di laut dan di daratan. Water bus memiliki dua sistem penggerak, yaitu roda pada di darat da penggerak propeller layaknya perahu atau kapal untuk melaju di perairan.

\section{METODOLOGI PENELITIAN}

\section{A. Pengumpulan Data}

Pada tahap ini dilakukan pengumpulan data yang relevan untuk menjadi patokan dari proses perancangan Water School Bus. Metode yang dilakukan dalam pengumpulan adalah secara tidak langsung (data sekunder). Data yang dibutuhkan adalah sebagai berikut:

a. Data Kapal

b. Data Jumlah Pelajar 


\section{B. Studi Literatur}

Pada tahap ini dilakukan pembelajaran dan pengumpulan teori-teori yang menunjang perancangan Water School Bus dan berkaitan dengan kapal amfibi, passenger ship, perhitungan metode forecasting untuk menentukan data, perhitungan pemilihan water jet sebagai penggerak kapal, perhitungan trim dan stabilitas kapal, freeboard, dan biaya pembangunan kapal.

\section{Operational Requirement dan Payload}

Penentuan payload dari kapal amfibi Water School Bus dilakukan dengan forecasting data jumlah siswa SMP di pulau untung Jawa yang melanjutkan sekolah ke tingkat SMA.

\section{Ukuran Utama Kapal}

Penentuan ukuran utama awal mengacu pada kapal pembanding yang sesuai dengan kapal yang akan didesain. Setelah ditentukan pembanding yang sesuai, ukuran tersebut divariasi dan dipilih untuk dijadikan ukuran sementara untuk perhitungan selanjutnya. Bila kedepannya ditemukan ketidaksesuaian ukuran kapal terhadap sifat kapal, ukuran ini bisa disesuaikan.

\section{E. Analisis Teknis}

Perhitungan teknis dilakukan sesuai dengan literatur yang dipelajari untuk menentukan kebutuhan desain kapal. Hal tersebut meliputi perhitungan hambatan kapal, power mesin kapal, penentuan propulsi, perhitungan berat kapal, perhitungan lambung timbul (freeboard), stabilitas dan trim kapal.

\section{F. Desain Rencana Garis, Rencana Umum dan 3D Model}

Pembuatan Rencana Garis (Lines Plan) dilakukan dengan membuat model lambung dan didesain body plan, sheer plan, serta half-breadth plan. Sedangkan untuk pembuatan Rencana Umum (General Arrangement) dilakukan setelah mengerjakan Lines Plan karena membutuhkan outline dari rencana garis lalu dilengkapi dengan machinary, equipment, outfitting dan detail lainnya. Untuk pembuatan gambar 3 dimensi dilakukan setelah rencana umum (General Arrangement) selesai.

\section{G. Kesimpulan}

Setelah semua tahapan selesai dilaksanakan, kemudian ditarik kesimpulan dari analisis dan perhitungan.

\section{ANALISIS TEKNIS}

\section{A. Perencanaan Muatan (Payload)}

Payload dari kapal amfibi Water School Bus adalah pelajar SMA dari Pulau Untung Jawa. Dikarenakan tidak adanya pendidikan SMA di pulau tersebut, data tersebut di ambil dari data jumlah pelajar SMP di Pulau Untung Jawa yang diasumsikan melanjutkan pendidikan SMA, dan diolah dengan metode forecasting (peramalan) sehingga didapatkan data jumlah penumpang kapal amfibi water school bus. Data diambil dari tahun 2013-2016 dan diramal 4 (empat) tahun mendatang yaitu untuk tahun 2017-2020. Didapatkan jumlah pelajar SMA di Pulau Untung Jawa hingga tahun 2020 sebesar 118 orang sehingga dibutuhkan 2 (dua) fleet kapal amfibi water school bus dengan kapasitas 60 orang.

\section{B. Kecepatan Water School Bus}

Dalam menentukan kecepatan dari kapal amfibi water school bus, ada beberapa faktor yang mempengaruhi yaitu jarak pelayaran, dan durasi perjalanan yang berkaitan dengan jam masuk sekolah di Jakarta Utara. Jarak dari Pulau Untung Jawa ke Muara Angke, Jakarta Utara, adalah $12.98 \mathrm{~km}$ sedangkan jam masuk sekolah adalah pukul 06.30 pagi. Direncanakan durasi pelayaran adalah 50 menit sehingga dengan rumus kecepatan, didapatkan nilai kecepatan kapal yaitu 8.41 knot.

\section{Perencanaan Ukuran Utama}

Dalam menentukan ukuran utama kapal, diambil data bus amfibi existing dari Belanda yang berikutnya diolah dengan metode 256 sehingga menghasilkan 256 variasi ukuran utama. Dengan constraints Peraturan Pemerintah no. 55 Tahun 2012, batasan ukuran bus yang diperbolehkan berjalan di jalanan umum, dipilih ukuran utama kapal amfibi water school bus dengan ukuran utama $\mathrm{Lpp}=14.27 \mathrm{~m}, \mathrm{~B}=2.5 \mathrm{~m}, \mathrm{H}=4 \mathrm{~m}, \mathrm{~T}=$ $1.6 \mathrm{~m}$.

\section{Perhitungan Hambatan Kapal}

Perhitungan nilai hambatan kapal meliputi frictional resistance, wave making resistance, dan air resistance. Didapatkan nilai rekapitulasi hambatan kapal seperti pada Tabel 1.

Tabel 1.

Rekapitulasi Nilai Hambatan Kapal

\begin{tabular}{cc}
\hline \hline Variabel Hambatan & Nilai (ton) \\
\hline Frictional Resistance & 0.176 \\
Wave Making Resistance & 1.737 \\
Air Resistance & 0.026 \\
Total Resistance $\left(\sum 1+2+3\right)$ & 1.939 \\
\hline \hline
\end{tabular}

\section{E. Pemilihan Mesin}

Dalam pemilihan mesin-mesin yang bekerja pada kapal amfibi water school bus, perlu dihitung kebutuhan daya baik untuk mesin induk, mesin bantu dan tenaga propulsinya. Dari perhitungan didapatkan kebutuhan BHPmcr dari kapal sebesar 461.2 HP (343.9 kW) sehingga dipilih permesinan seperti pada Tabel 2.

Tabel 2.

Spesifikasi Mesin Penggerak Kapal

\begin{tabular}{ccc}
\hline \hline Jenis & Tipe & Power \\
\hline Mesin Induk & CAT C9 ACERT & $503 \mathrm{HP}$ \\
Waterjet & THRUSTMASTER 100 SERIES & $510 \mathrm{HP}$ \\
Mesin Bantu & KOHLER 21EKOZD & $21 \mathrm{~kW}$ \\
Gearbox & ALLISON TRANSMISSON & $550 \mathrm{HP}$ \\
\hline \hline
\end{tabular}

F. Perhitungan Berat dan Titik Berat Kapal

Kapal terdiri atas lightweight (LWT) dan deadweight (DWT) yang merupakan berat kapal kosong dan berat muatan dari kapal. Untuk perhitungan jarak titik berat kapal dapat dibagi menjadi dua macam, yaitu jarak titik berat secara memanjang (longitudinal center of gravity/LCG) untuk mengetahui dimana letak titik berat secara memanjang dengan acuan AP, midship, atau FP. Sedangkan jarak titik berat secara vertikal (vertical center of gravity/VCG) digunakan untuk mengetahui letak titik berat dari dasar lunas (keel) sebagai titik acuannya. Rekapitulasi berat LWT, DWT, serta titik berat pada kapal dapat dilihat pada Tabel 3. 
Tabel 3.

Rekapitulasi Berat dan Titik Berat Kapal

\begin{tabular}{c|c}
\hline \hline LWT (ton) & 19.4 \\
DWT (ton) & 29.159 \\
Berat Total (ton) & 48.553 \\
Displacement (ton) & 48.738 \\
VCG from Baseline (m) & 0.975 \\
LCG from Midship (m) & 0.712 \\
LCG from AP (m) & 7.848 \\
\hline \hline
\end{tabular}

\section{G. Pemeriksaan Stabilitas}

Analisis stabilitas digunakan untuk mengetahui keseimbangan kapal secara melintang pada beberapa kondisi pemuatan (loadcases). Kriteria stabilitas yang digunakan mengacu pada Intact Stability Code 2008 [8]. Dilakukan pemeriksaan pada 14 kondisi yaitu Loadcase 1 pada saat muatan dan consumable penuh, Loadcase 2 saat muatan penuh dan consumable kosong, Loadcase 3 saat muatan setengah terisi dan consumable penuh, Loadcase 4 saat muatan setengah terisi dan consumable kosong, Loadcase 5 saat muatan kosong dan consumable penuh, dan yang terakhir Loadcase 6 ketika muatan kosong dan consumable kosong. Lalu kondisi A adalah ketika posisi penumpang tersebar merata, kondisi B ketika posisi penumpang tersebar di sisi kiri kapal dan kondisi C ketika posisi penumpang tersebar di sisi kanan kapal. Adapun hasil pemeriksaan stabilitas telah memenuhi seluruh kriteria dan dapat dilihat pada Tabel 4.

Tabel 4.

Rekapitulasi Pemeriksaan Stabilitas

\begin{tabular}{|c|c|c|c|c|c|c|c|}
\hline \multirow{3}{*}{$\begin{array}{l}\text { Load } \\
\text { Case }\end{array}$} & \multicolumn{7}{|c|}{ Kriteria } \\
\hline & $\begin{array}{c}\text { Area } 0 \\
\text { to } 30\end{array}$ & $\begin{array}{c}\text { Area } 0 \\
\text { to } 40\end{array}$ & $\begin{array}{c}\text { Area } \\
30 \text { to } \\
40\end{array}$ & $\begin{array}{l}\text { Max GZ } \\
\text { at 30 or } \\
\text { greater }\end{array}$ & $\begin{array}{c}\text { Angle } \\
\text { of } \\
\text { Max } \\
\text { GZ }\end{array}$ & $\begin{array}{c}\text { Initial } \\
\text { GMt }\end{array}$ & $\begin{array}{c}\text { Passenger } \\
\text { Crowding } \\
\text { Angle }\end{array}$ \\
\hline & $>0.055$ & $>0.09$ & $>0.03$ & $>0.2$ & $>25$ & $>0.15$ & $<10$ \\
\hline $1 \mathrm{~A}$ & 0.093 & 0.157 & 0.065 & 0.54 & 68.2 & 0.489 & 6.9 \\
\hline $1 \mathrm{~B}$ & 0.104 & 0.172 & 0.068 & 0.54 & 67 & 0.489 & 4.2 \\
\hline $1 \mathrm{C}$ & 0.081 & 0.143 & 0.061 & 0.54 & 68.2 & 0.489 & 9.5 \\
\hline $2 \mathrm{~A}$ & 0.103 & 0.182 & 0.078 & 0.56 & 66.4 & 0.657 & 7.6 \\
\hline $2 B$ & 0.115 & 0.197 & 0.081 & 0.56 & 66.4 & 0.657 & 5.6 \\
\hline $2 \mathrm{C}$ & 0.091 & 0.166 & 0.075 & 0.56 & 67 & 0.657 & 9.7 \\
\hline $3 \mathrm{~A}$ & 0.092 & 0.158 & 0.066 & 0.54 & 68.2 & 0.516 & 7.8 \\
\hline $3 B$ & 0.101 & 0.169 & 0.069 & 0.54 & 67 & 0.516 & 5.9 \\
\hline $3 C$ & 0.086 & 0.150 & 0.064 & 0.54 & 68.2 & 0.516 & 9.2 \\
\hline $4 \mathrm{~A}$ & 0.102 & 0.181 & 0.079 & 0.56 & 66.4 & 0.677 & 8.4 \\
\hline $4 B$ & 0.111 & 0.192 & 0.081 & 0.56 & 66.4 & 0.677 & 6.9 \\
\hline $4 C$ & 0.095 & 0.172 & 0.077 & 0.56 & 66.4 & 0.677 & 9.5 \\
\hline 5 & 0.086 & 0.149 & 0.063 & 0.54 & 68.2 & 0.499 & - \\
\hline 6 & 0.067 & 0.122 & 0.055 & 0.54 & 68.2 & 0.454 & - \\
\hline
\end{tabular}

\section{H. Perhitungan Trim}

Trim adalah keadaan kapal ketika sarat depan dan sarat belakang memiliki nilai selisih, sehingga kapal condong pada salah satu sisi dan tidak mengalami even keel. Kondisi maksimum dari trim adalah 0,5\% dari $\mathrm{Lww}_{\mathrm{L}}$ [9] sehingga pada kapal amfibi Water School Bus, trim yang diizinkan maksimum bernilai $0.07 \mathrm{~m}$ sehingga dapat disimpulkan bahwa trim dari kapal ini memenuhi persyaratan dan sifatnya adalah trim by stern. Trim kapal dapat dilihat pada Tabel 5 .

Tabel 5.

Rekapitulasi Nilai Trim Kapal

\begin{tabular}{ccccc}
\hline \hline Loadcase & $\mathrm{T}_{\mathrm{A}}(\mathrm{m})$ & $\mathrm{T}_{\mathrm{F}}(\mathrm{m})$ & $\mathrm{T}_{\mathrm{A}}-\mathrm{T}_{\mathrm{F}}(\mathrm{m})$ & Status \\
\hline Kondisi 1 & 1.64 & 1.573 & 0.067 & Accepted \\
Kondisi 2 & 1.569 & 1.517 & 0.052 & Accepted \\
Kondisi 3 & 1.594 & 1.541 & 0.053 & Accepted \\
Kondisi 4 & 1.527 & 1.481 & 0.046 & Accepted \\
Kondisi 5 & 1.531 & 1.462 & 0.069 & Accepted \\
Kondisi 6 & 1.46 & 1.406 & 0.054 & Accepted \\
\hline \hline
\end{tabular}

\section{Perhitungan Freeboard}

Perhitungan nilai minimum lambung timbul (freeboard) untuk kapal amfibi Water School Bus mengacu pada Korean Register Rules [10] dikarenakan bentuk lambung kapal yang seperti barge. Nilai freeboard pada kapal ini adalah $2400 \mathrm{~mm}$, sedangkan nilai minimum freeboard untuk kapal amfibi Water School Bus sebesar $125.516 \mathrm{~mm}$.

\section{J. Desain Rencana Garis dan Rencana Umum}

Rencana Garis adalah gambar proyeksi badan kapal yang dipotong secara melintang (body plan), secara memanjang (sheer plan), dan vetikal memanjang (half breadth plan). Proses pembuatan desain rencana garis dimulai setelah ukuran utama kapal diketahui. Rencana Umum adalah perencanaan ruangan pada kapal, yang disesuaikan dengan fungsi, kebutuhan dan perlengkapan kapal yang mengacu pada Rencana Garis [11]. Adapun desain Rencana Garis dan Rencana Umum Water School Bus ini dapat dilihat pada Gambar 7. dan Gambar 8.

\section{K. Desain 3 Dimensi}

Proses pembuatan desain 3 dimensi mengacu pada General Arrangement. Model 3 dimensi dapat dilihat pada Gambar 4, Gambar 5, dan Gambar 6.

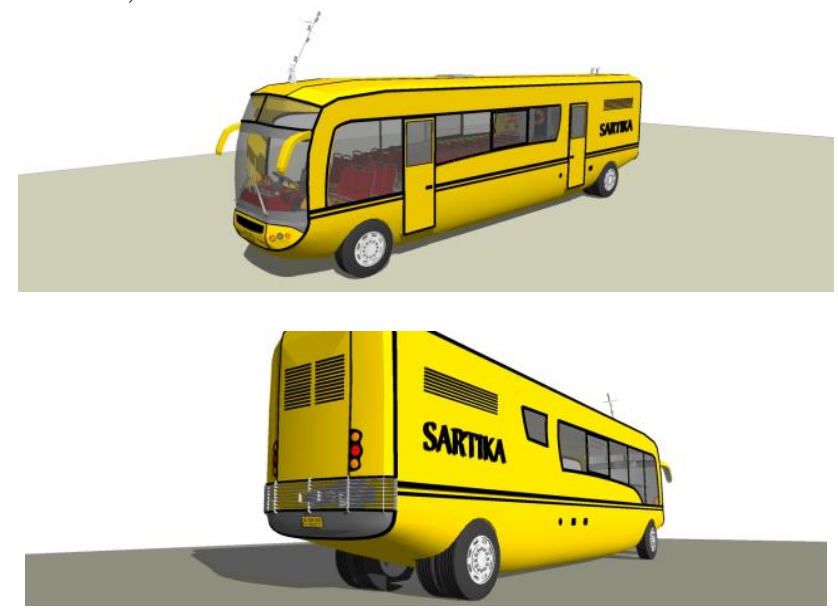

Gambar 4. Eksterior Kapal Amfibi Water School Bus 


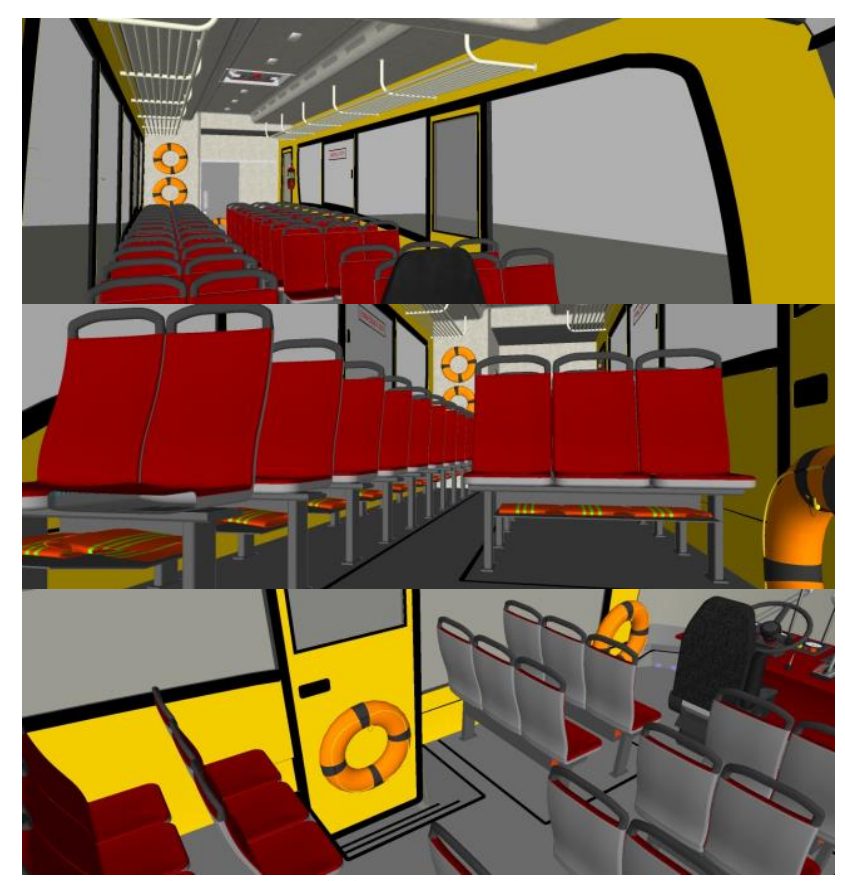

Gambar 5. Interior Kapal Amfibi Water School Bus

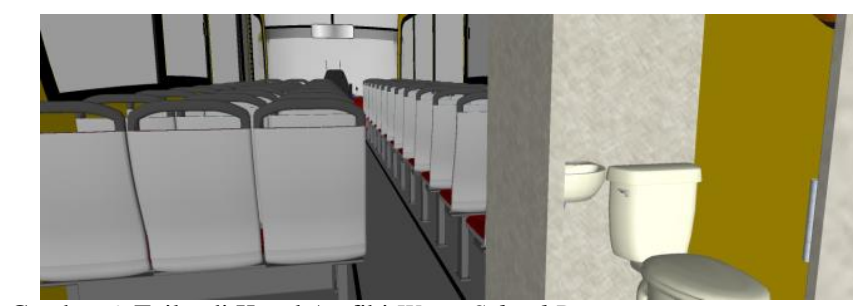

Gambar 6. Toilet di Kapal Amfibi Water School Bus

\section{Sistem Kekedapan}

Sistem kekedapan pada kapal amfibi Water School Bus dibutuhkan pada bagian pintu dan jendela kapal. Water School Bus menggunakan jendela dan pintu watertight yang terbuat dari baja dan pada bagian pinggirnya dipasang karet rubber seal untuk menahan masuknya air.

\section{Biaya Pembangunan}

Biaya pembangunan kapal terdiri atas beberapa komponen, yaitu biaya baja kapal, motor penggerak kapal, dan equipment \& outfitting. Didapatkan nilai biaya yang dibutuhkan untuk membangun kapal ini sebesar Rp 2,393,414,848.59

\section{KESIMPULAN}

Berdasarkan uraian di atas, dapat diambil kesimpulan sebagai berikut:

1) Ukuran utama yang didapat adalah: $\mathrm{Lpp}=14.27 \mathrm{~m}, \mathrm{~B}=$ $2.5 \mathrm{~m}, \mathrm{~T}=1.6 \mathrm{~m}, \mathrm{H}=4 \mathrm{~m}$

2) Dihasilkan gambar Rencana Garis, Rencana Umum, dan Desain 3D dari kapal amfibi Water School Bus.

3) Dihitung biaya pembangunan Water School Bus sebesar Rp 2,393,414,848.59

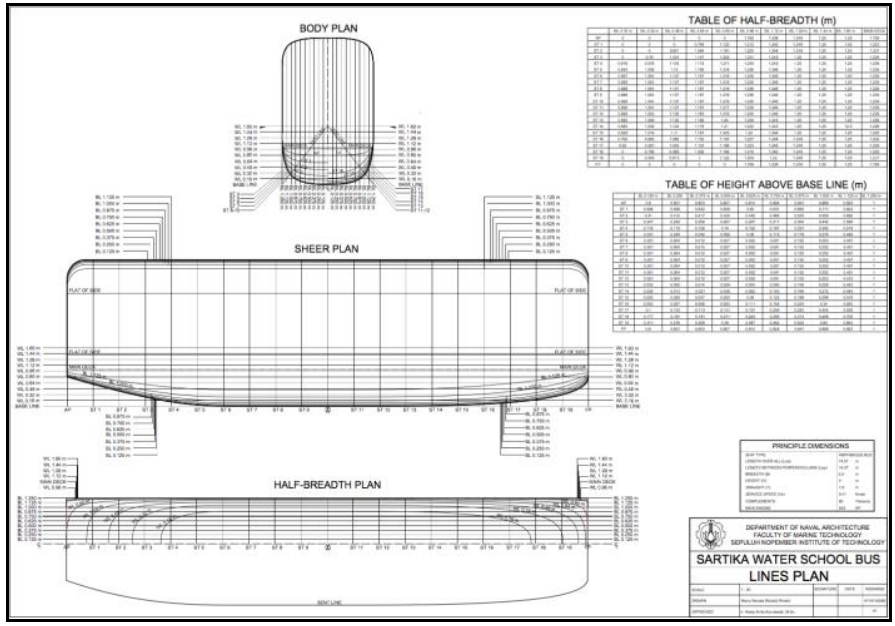

Gambar 7. Desain Rencana Garis Water School Bus

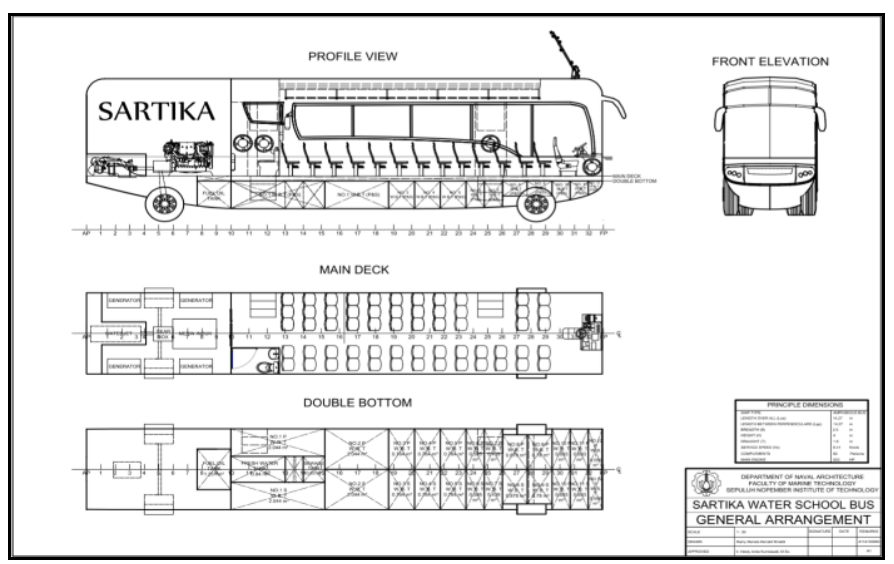

Gambar 8. Desain Rencana Umum Water School Bus

\section{DAFTAR PUSTAKA}

Anonim, "Kabupaten Administrasi Kepulauan Seribu," www.pulauseribu.jakarta.go.id, 2017. [Online]. Available: www.pulauseribu.jakarta.go.id.

[2] Indopos, Tiga Unit Kapal sekolah di Kepulauan Seribu Kembali Beroperasi. 2017.

[3] J. H. Evans, "Basic Design Concept," Nav. Eng. J., vol. 71, 1959.

[4] A. M. Yusuf, Metode Penelitian: Kuantitatif, Kualitatif, dan Penelitian Gabungan (1st Edition ed.). Jakarta: Kencana, 2014.

[5] S. W. Adji, "Water Jet Propulsion System," 2009.

[6] K. Badan Pusat Statistik, Kepulauan Seribu Selatan Dalam Angka. BPS Kabupaten Kepulauan Seribu, 2017.

[7] N. F. Adiba, "Desain Trash Skimmer Amphibi-Boat di Sungai Ciliwung Jakarta," 2016.

[8] I. M. Organization, Intact Stability (IS) Code. London: IMO, 2008.

[9] I. M. Organization, International Convention for the Safety of Life at Sea. London: IMO, 1988.

[10] K. R. (KR), Rules for Towing Survey of Barges and Tugboats perubahan dari (Rules 1999). 2010.

[11] R. Taggart, Ship Design and Construction Chapter 5. SNAME, 1980. 